DOI: https://doi.org/10.34069/AI/2022.49.01.9

How to Cite:

Pavliuchenko, Y., Pysarieva, E., Turchenko, O., Sukhanova, D., \& Skrypnyk, D. (2022). The rule of law principle in the practice of the ECtHR and national courts. Amazonia Investiga, 11(49), 76-85. https://doi.org/10.34069/AI/2022.49.01.9

\title{
The rule of law principle in the practice of the ECtHR and national courts
}

\section{Принцип верховенства прав в практиці ЄСПЛ та національних судах}

Received: December 12, 2021

Accepted: January 17, 2022

\author{
Written by: \\ Yuliia Pavliuchenko ${ }^{31}$ \\ https://orcid.org/0000-0003-1504-8384 \\ Ella Pysarieva ${ }^{32}$ \\ https://orcid.org/0000-0001-9706-1739 \\ Olha Turchenko ${ }^{33}$ \\ https://orcid.org/0000-0001-7446-1289 \\ Daria Sukhanova ${ }^{34}$ \\ https://orcid.org/0000-0003-2060-3792 \\ Daria Skrypnyk ${ }^{35}$ \\ https://orcid.org/0000-0002-1584-0120
}

\begin{abstract}
The study aims to reveal the constituent elements of the rule of law (RL), highlighted by the case law of the European Court of Human Rights and individual national courts. It also analyses the feasibility of implementing and consolidating such isolation as a way to overcome the declarative nature of the RL. The versatility of the meanings and content of this principle, its declarative nature of existence and consolidation gives rise to a number of issues, the absence of a solution to which is primarily manifested by the presence of negative consequences in practice, in particular, according to the generally recognized selection of the components of the principle of the RL (PRL), it is advisable and relevant to study official interpretations of the RL. The aim of the work is to identify some fundamental interpretations of the PRL to overcome its declarativeness. The methodological basis of the work consists of the following methods: dialectical, epistemological, functional, axiological, comparative legal method, method of system-structural analysis, method of generalization. The main conclusions are that the interpretation of the RL by the relevant judicial
\end{abstract}

\footnotetext{
${ }^{31}$ Doctor of Legal Sciences, Associate Professor, Acting Head of the Department of Economic and Administrative Law, Vasyl Stus Donetsk National University, Ukraine.

${ }^{32}$ Ph. D., Associate Professor, Acting Head of the Department of Civil Law and Procedure, Vasyl Stus Donetsk National University, Ukraine.

${ }^{33} \mathrm{Ph}$. D., Associate Professor, Head of the Constitutional, International and Criminal Law Department, Vasyl Stus Donetsk National University, Ukraine.

${ }^{34}$ Ph.D., Associate Professor of the Department of State and Legal Disciplines of Odessa State University of Internal Affairs, Ukraine.

${ }^{35}$ Lawyer, Ph.D. candidate of the Department of Criminal Procedure, Detective and Operational Investigation of the National University "Odessa Law Academy", Ukraine.
} 


\section{$\frac{\text { AMAZONDA }}{\text { Drvestiga }}$}

bodies reveals and consolidates the multifaceted content of this principle, but the lack of systematization of such interpretation's risks creating complications in its practical application.

Keywords: rule of law, constitutionalism, human rights and fundamental freedoms, limits of state intervention, principle of legal certainty.

\section{Introduction}

Development of society, and with it the complication of relations «the state-human» system now requires the state to strengthen its position on recognizing man as the greatest social value and granting him appropriate privileges, maximizing respect for human rights, and creating favorable conditions for both participants in the system to maintain a balance of interests and goals. Such challenges of modernity lead to the formation of a critical vision of the existing constitutionalism of each individual state, which does not exist separately from other participants in the international political arena, and is therefore significantly influenced by the latter, especially when it comes to influence supranational organization, whose authority is recognized at the international level. Thus, the European Court of Human Rights (ECtHR) is a body whose jurisdiction extends to states that have signed the European Convention on Human Rights (hereinafter - the Convention) (Verkhovna Rada of Ukraine, 1950), so the conclusions set out in ECtHR judgments are binding on national courts of signatory states to the Convention, which, based in particular on this practice, can draw their own conclusions on the vision of certain issues. The legal realities of today require the consolidation of practical and theoretical achievements around the accomplishment of common goals, one of which can be considered the construction and dissemination of a strong model of effective constitutionalism, which must meet the requirements of modern civilized society. In turn, modern true constitutionalism cannot exist without the state's RL, which has historically been the basis of state governance, but the rapid development of society against the background of social, political, economic processes necessitates a rethinking of the declarative consolidation of the RL internationally and nationally. узагальнення. Основні висновки полягають в тому, що тлумачення відповідними судовими органами принципу верховенства права розкриває та закріплює багатоаспектний зміст вказаного принципу, проте відсутність систематизації таких тлумачень ризикує створити ускладнення в його практичному застосуванні.

Ключові слова: верховенство права, конституціоналізм, права та основоположні свободи людини, межі втручання держави, принцип правової визначеності.

Thus, unquestioning observance of the RL is the primary task of any constitutional state governed by the RL. The PRL is a multifaceted ideological vector of the state as a whole, as it contains derivatives of such general principles as justice, equality, freedom, humanism, and so on. The RL forms the value image of the legal system and ensures the existence of true ideological constitutionalism in legal reality.

Within the framework of constitutionalism, the interpretation of the ECtHR and national courts of one of the most important principles of building a civilized and democratic state - the PRL - is of great importance. The interpretation of the PRL of the ECtHR at the international level, as well as other national judicial institutions locally, now serves as a basis for an in-depth understanding of this principle, which will highlight its main components. Consolidation of the RL is the lack of a clear legal definition of its content, which may result in the leveling of this principle due to the fact that the lack of its characteristics complicates the monitoring of violations. Moreover, generally accepted adherence to the ECtHR's legal position on the view of the RL by national courts should also be seen as a step towards the approximation of the laws of different states to each other at the level of constitutional doctrine.

The object of the study is the legal relationship within the interpretation of the RL by the European Court of Human Rights and individual national courts.

The subject of the research is the PRL in the practice of the European Court of Human Rights and the national courts of states. 


\section{Theoretical Framework or Literature Review}

Due to the fact that the RL is not a new principle, its features have been studied by many scholars and practitioners in various fields of law.

For example, Bratasyuk (2015) studied the PRL as a constitutional basis of legal development, so he linked it, in particular, with such ideological concepts as justice, freedom, RL in society, spiritual and cultural phenomenon and more. Scholars have considered the PRL through the prism of the positions of natural law doctrine, which are embodied in the Constitution of Ukraine. The scientist once again proved that this principle should be considered a mega-principle. The works of Kozyubra, Pogrebnyak and Tselieva (2015) in the field of theory of state and law should be attributed to the disclosure of philosophical understanding of the PRL, its place among the values of the legal field. It is also important to compare this principle with the RL, within which it is established that both have common heterogeneous sub-principles, the combination of which determines the main purpose of the RL.

It is worth noting that Matveeva (2019) focused on the principle of legal certainty as an integral element of the PRL. The scientist devoted her research to establishing the essence of the principle of legal certainty as a component of the PRL, revealing its basic meaning and evolution, as well as defining requirements for compliance with the principle of legal certainty in law enforcement and rulemaking. Thus, the scientist has made a significant contribution to understanding the PRL through the prism of the principle of legal certainty.

The case law of the European Court of Human Rights as a system of interconnected and established principles, which together define the concept of the doctrine of the RL, was studied by Temchenko (2007). His works analyze some decisions of the ECtHR that are important for understanding the RL, as well as identify the main groups of principles of the RL: the principles of the RL on the form of law, the principles of the RL on the essence of RL, the RL in justice.

A significant contribution to the structuring of ECtHR practice within the RL was made by Pukhtetska (2010), who proposed and developed the idea of classifying such practice into groups according to the criterion of requirements for the content of the RL. In addition, the author's study of the formation and change of scientific views on the content of the RL is of great importance given the impact of European integration processes, which in turn showed the imperfection of the current RL compared to European standards.

The achievement of Butkevych (2011), as an experienced practitioner and former judge of the European Court of Human Rights, is, in particular, that he identified five core values, which include the RL and which this principle requires adherence to. These achievements have significantly developed and strengthened the position on the need to follow the case law of the European Court of Human Rights in order to understand the content of the RL.

Such a new branch of law as sports law is actively formed on the general legal principles, one of the main of which is the RL. Problems of sports law in general, and ensuring the rule of law in the field of sports in particular, are engaged in Ukrainian researchers Kharytonov, Kharytonova, Tkalych, Bolokan, Samilo, and Tolmachevska (2021); Kolomoiets, T., Tkalych, M., Melnyk, P., Panchenko, B., \& Tolmachevska, Y. (2021); Kharytonov, E., Kharytonova, O., Kostruba, A., Tkalych, M., \& Tolmachevska, Y. (2020); Bolokan, I., Samoylenko, G., Tkalych, M., Panchenko, B., \& Dmytriv, V. (2021).

At the same time, despite a significant amount of scientific research, the practical issue of the declarative nature of the existence of the PRL remains unresolved, in connection with which the analysis of the practice of the ECtHR and national courts in the framework of the vision of this principle can serve as an effective option for eliminating this declarativeness, therefore, requires further study.

\section{Methodology}

Both general and special methods were used in the research, thanks to which the set result was achieved and appropriate conclusions were made, which are important to further improve the understanding and consolidate the PRL.

Thus, the dialectical method has helped to establish a modern vision of the RL, as well as the relationships and features that arise in its interpretation and application. It became achievable to examine the $\mathrm{RL}$ as a legal phenomenon, consisting of a set of interrelated elements that somehow reinforce each other, filling and revealing the content of this principle. 


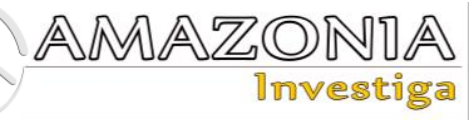

The epistemological method contributed to a comprehensive consideration of the main legal positions of the European Court of Human Rights on the application of the RL and understanding of their meaning and essence by analyzing scientific sources, relevant legal acts and court decisions.

Using the method of system-structural analysis revealed the content of the concept of the RL, the essence of its declarative consolidation and identified a number of its constituent elements, which in turn served to assess the need for further interpretation of the RL by ECtHR and national courts and the application of existing judicial legal interpretations.

The functional method was used to clarify the main purpose of the RL and its main constituent elements, which is determined by the ECtHR, and the national courts of individual states. Thus, with the help of this method it was established, in particular, that the PRL serves the purpose of recognition at the international and national levels of human rights and freedoms, their observance and protection.

The axiological method is the basis of conclusions about the value of the PRL and overcoming its declarativeness to build a strong constitutional state governed by the RL. This method made it possible to perceive the RL through the prism of its interpretations as a crucial legal phenomenon, an element of culture and legal reality, socio-cultural phenomenon, as well as highlighting the value of its proper understanding and consolidation in order to achieve quality, democratic, social state system «The state-human».

Gratitude to the comparative-legal method, we corresponded specific legal positions on the interpretation of the RL by the national courts of the signatory states. The study analyzes some emphasis on the attitude and understanding of the RL by such courts of constitutional jurisdiction as the Constitutional Court of Ukraine, the Constitutional Court of the Republic of Lithuania, the Federal Constitutional Court of Germany and concludes that such interpretations are necessary by national courts, as the latter is as consistent as possible with the perception of this principle within a particular state.

The method of generalization allowed to draw attention to the existing problems of observance of the RL, which are related, in particular, to the declarative nature of its existence, which in turn complicate the practical application of this principle in the legislative, executive and judicial branches.

The logical-legal method made it possible to consider the possibility of consolidating the universally recognized components of the $\mathrm{RL}$ as a solution to the problem of its declarativeness, as well as to note the need for future consideration of a relevant database containing legal conclusions courts of each individual state in order to optimize the application of interpretations of this principle.

\section{Results and Discussion}

Given the multifaceted nature of this principle, the general vision of constitutionalism and its role in the system of relations between the state and the individual depends on its understanding, interpretation and, as a consequence of perception. That is why the concept of the RL in the practice of the ECtHR occupies a special place and is explained in a significant number of its decisions from different angles, which at the same time reveal the essence of this fundamental principle.

It should be noted that the Convention for the Protection of Human Rights and Fundamental Freedoms (Verkhovna Rada of Ukraine, 1950) itself, which is interpreted by the ECtHR, does not contain a separate enshrinement of the RL, but the Convention, as an international source of law, is based on the PRL, which protects human rights and fundamental freedoms.

For example, in the judgment in Golder v. The United Kingdom, the ECtHR set out only one task to uphold the RL: human rights have a broader meaning than the right conferred on it by the state (Application No. 4451/70, A/18, 1997). However, according to the author, the problematic aspect of the RL is the declarative nature of its consolidation, as the Convention itself, as well as other international legal acts of the same force as the Convention, do not contain a clear definition of this principle, which significantly complicates its practical application and, as a consequence, the establishment of a violation of this principle. The solution to this problem could be a normatively established separation of components of the RL, which would determine its content.

The lack of a universal, comprehensive definition of the RL does not mean that it is a political declaration or doctrinal abstraction, as some politicians and sometimes legal scholars (usually proponents of legal positivism) believe. It is 
customary to reveal the content of the RL mainly through its most essential features. Some foreign scientists have more than a hundred of such components (Kozyubra, Pogrebnyak, Tselev, \& Matveeva, 2015).

At the same time, it is crucial in the process of clarifying the content of the RL in the context of its application to understand the RL as a single and indivisible principle, which, although consisting of separate elements, can be realized only if they are united. According to Kryzhova (2016), it is also necessary to be extremely careful about including one or another element in this principle, as there is a certain risk of excessive expansion of its content. This situation seems undesirable, because the clearer defined the PRL, the closer the prospect of its proper reflection in regulations and law enforcement. Similarly, oversimplification of this principle will have negative consequences, as it will lead to a narrow interpretation of it and, consequently, to limited implementation. Therefore, it is extremely important to determine the optimal structure of the RL, which will allow to establish its effective enforcement within the relevant legal system (Kryzhova, 2016).

According to the author, the beginning of the definition of the components of this principle was laid by the ECtHR, which by its decisions reveals the components of the RL and establishes vectors of good behavior of states, following which the RL can be considered.

Characterizing the common vision of the ECtHR on the PRL, it should be noted that the ECtHR interprets this principle as the rule of human rights and freedoms, as well as the priority of their provision. The ECtHR is convinced that the $\mathrm{RL}$ is a concept common to all articles of the Convention, as stated in the ECtHR judgment in Shchokin v. Ukraine (Application No. 23759/03, 2010). Such an understanding by the ECtHR of this principle may also mean that the latter interprets it quite broadly, in connection with which a violation of any article can be regarded as a violation of the PRL.

Thus, the RL is applied in the practice of the ECtHR not only in terms of disclosing its general content, but also is reflected in individual human rights in relation to the relevant circumstances. In the context of the above, it is worth paying attention to the main legal positions of the ECtHR, set out in its decisions, which allow to fully describe the relationship of the latter to the PRL.
Thus, the decisions of the European Court of Human Rights, which are aimed at disclosing the content of the quality of law within the RL, are important. A selective analysis of this group of decisions allows us to conclude that the ECtHR attaches to the essence of the RL the right to establish a state level of regulation of relevant relations, which would be clear to everyone and unconditionally observed by the relevant authorities.

In particular, in the judgment Kruslin v. France, the ECtHR, in interpreting Article $8 \S 2$ of the Convention, stated the following: At the same time, this provision implies the quality of a particular law. It requires that the law be made available to the person concerned, who can foresee the consequences of its application to himself, and that the law not be contrary to the RL. The decision also stated that the wording of the law should be clear and understandable enough to provide citizens with the necessary information about the circumstances and conditions under which public authorities are authorized to covertly and potentially dangerous interference with the exercise of individual rights (Application No. 11801/85, 1990).

Or, for example, in the Amuur v. France judgment, the ECtHR stated that the quality of a law requires that it be compatible with the RL, a provision which applies to all articles of the Convention (Application No. 19776/92, 1996), and in the case of Funke v. France clarified that the "quality" of domestic law under the Convention depends on the accuracy with which legislation and case law determine the scope and conditions of exercise of power, excluding the danger of arbitrariness (Application No. 10828/84, 1993).

Thus, the RL, according to the ECtHR, is directly dependent on the quality of the law, or rather the latter is part of this principle. The author believes that such a vision obliges states to carefully formulate a national legal framework, as well as to take measures to carry out educational work among the population within legal issues.

In turn, the "quality" of the law is closely linked to the principle of legal certainty.

In the text of the Convention, the principle of legal certainty is expressed in the requirements: the existence of legal grounds for interference with the rights of the individual; legal certainty of the crime; creation of courts on the basis of law; legal regulation of the procedure for appealing verdicts in criminal cases and payment 


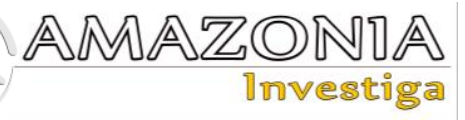

of compensation in case of miscarriage of justice; inadmissibility of re-conviction or punishment for crimes (Temchenko, 2007).

Consistent adherence to the principle of legal certainty contributes to a person's confidence in his stable legal position, in the formation of their own legal behavior with a clear perspective, stability and consistency of the entire legal system.

In order to coordinate their actions with the relevant regulations, a person must not only know them, but also anticipate the consequences of their behavior in certain life situations, that is, make their choices consciously and predictably. This is a guarantee of predictability and stability of society as a whole, which is aimed at ensuring legal regulation (Matveeva, 2019).

Indeed, adherence to the principle of legal certainty, which is derivative in nature, emphasizes the RL. However, the declarative nature of the latter mentioned above gives rise to its broad interpretation by both the ECtHR and other law enforcement agencies, which in turn may result in the inclusion of any legal principle in the RL or any activity of the state aimed at the implementation, protection and defense of individual rights. Thus, according to the author, there is a risk of devaluation of the RL due to its content overload, including other principles.

Given that the ECtHR is by legal nature a judicial body that interprets the provisions of the Convention in the context of appeals against national court decisions, access to justice and a fair trial are crucial in its work, which the ECtHR also understands as part of the RL.

Article 6 of the Convention (Verkhovna Rada of Ukraine, 1950) proclaims, inter alia, the right of everyone to a fair and public hearing within a reasonable time by an independent and impartial tribunal established by law to decide a dispute concerning his civil rights and obligations or to establish the merits of any criminal charges against him.

Given that the basic idea of law as a regulator of social relations should be to establish the value of man, the protection of his rights and interests is the basis of the RL, as it serves its overall purpose. Thus, the PRL directly relates to the possibility of a person exercising his right to protection, in particular judicial. The violation by the state of a person's right to access to justice and fair trial is in its very nature contrary to the $\mathrm{RL}$, as the latter cannot be respected due to the person's inability to apply to the authorities to initiate appropriate protection proceedings.

The link between judicial protection and the RL is addressed: in the judgment of the ECHR "Hornsby v. Greece", where the ECtHR emphasizes that the right to a fair trial should be interpreted through the preamble to the Convention, which in the relevant part proclaims the RL as part of the common heritage of the Contracting States. One of the fundamental aspects of the RL is the principle of legal certainty, which, among others, requires that final judgments be not called into question (Application No. 18357/91, 1997).

The decisions of the ECHR also show that the PRL includes requirements to limit the arbitrariness of public authorities to interfere in the exercise of human rights and freedoms. For example, in Olsson v. Sweden, the ECtHR found that compliance with the RL required "the existence of appropriate safeguards in domestic law against arbitrary interference by public authorities with the exercise of rights" (Application No. 10465/83, 1988), and in the decision in the case of Volokh v. Ukraine it stated the following: "... granting legal discretion to the executive branch in the form of unlimited powers would be incompatible with the PRL. Therefore, the law must define with sufficient clarity the limits of such discretion granted to the competent authorities and the procedure for its implementation, taking into account the legitimate aim of the measure to ensure adequate protection against arbitrary interference" (Application No. 474/32, 2006).

Thus, observance of the RL means, inter alia, the establishment of clear limits on state interference in the rights and freedoms of the individual, as on the one hand the RL allows some discretion of the relevant authorities on such interference, and on the other - prohibits crossing it. This is the manifestation of the regulation of relations dictating the manner of behavior of a person to the extent that it is enough to maintain a balance of interests between the parties to the interaction. Returning to the basic idea of the RL, namely to ensure respect for human rights, it is worth noting another component of this principle, which distinguishes the ECtHR - effective control over the exercise of human rights and fundamental freedoms. Simultaneously, such control should be ensured, first of all, both by the state and the public, as only the state has the appropriate range of mechanisms to ensure such control, and public participation will ensure quality and transparency of the above control by the state. 
In particular, the ECtHR judgment in Malone v. The United Kingdom provides that supervisory proceedings must respect the values of a democratic society as conscientiously as possible, including the RL, as explicitly stated in the Preamble to the Convention. The RL provides, inter alia, that interference by the executive with the rights of individuals should be subject to effective control, which should normally be exercised by the judiciary, at least as a last resort, as judicial control provides the greatest guarantees of independence, impartiality and independence. (Application No. 8691/79, 1984).

According to the author, an important role in ensuring control over human rights should be given not only to the judiciary, but also to monitoring, which can be carried out by both subjects of power and individuals, as the latter is aimed at protection.

In the judgment in Campbell and Fell v. The United Kingdom, the ECtHR, revealing the need for judicial guarantees of the RL, stated that public control over the judiciary was necessary to preserve and guarantee the right to a fair trial. In particular, this concerns the problem of the necessity and form of public announcement of a "judgment" (Application No. 7819/77, 1984).

The former judge of the European Court of Human Rights Butkevych (2011) proposes, given the lack of definition of the RL, to rely on five core values that reflect the RL and which this principle requires adherence to:

1) protection of human rights and freedoms;

2) the functioning of the state and its bodies related to the implementation of the law, the prohibition of state arbitrariness;

3) observance of the principle of equality of subjects of law (individuals and legal entities) before the law;

4) ensuring law and order in society;

5) the availability of effective and predictable justice (the right to access to court, the right to a fair trial, etc.).

All the above allows us to conclude that the RL is understood through the prism of natural law ideas about human rights and their place in the human-state system, and the ECtHR practice of interpretation and application of the Convention can be considered a shining example of legalization of such natural law ideas.

However, ECtHR decisions are usually taken into account by the judiciary in their proceedings.
However, given the declarative nature of the RL and the fact that this principle is the basis for building a constitutional state, the legal conclusions of the ECtHR should be taken into account by other branches of government in their decisions, as such decisions should be aimed at ensuring priority and effectiveness.

In turn, given the lack of a specific definition of the RL, national courts add a new color to its interpretation. Thus, it is possible to enshrine this principle in the constitutions of states, because, in particular, the RL is the basis of constitutionalism, and therefore their own vision of the RL is often expressed by courts of constitutional jurisdiction.

The norms of law revealed in the decisions of constitutional courts through the formation of legal positions are of a special interpretive nature, as they contain not only citations of the relevant norm, but also justification of its content and meaning, as in ECtHR decisions. Legal positions in this case should be understood as that part of the decision of the judicial body, which includes the consolidation of a special type of regulations, which, in turn, serves as an example to address issues that will arise in the future; in which the conclusions of the judges of the relevant court in considering a particular case are supported by certain grounds.

For example, the Constitutional Court of Ukraine in its decision of 2004 No. 15-rp / 2004 enshrined the understanding of the RL as the RL in society, and noted that the RL requires the state to implement it in lawmaking and law enforcement, including laws, which in their content should be permeated, above all, with the ideas of social justice, freedom, equality, etc. One of the manifestations of the RL is that law is not limited to legislation as one of its forms, but also includes other social regulators, including morals, traditions, customs, etc., which are legitimized by society and determined by the historically achieved cultural level. All these elements of law are united by a quality that corresponds to the ideology of justice, the idea of law, which is largely reflected in the Constitution of Ukraine (Case No. 1-33/2004, 2004).

It should be noted that this is not about the RL only in the state, but in society. The state, which must not have its own, partial interest other than society, must embody the idea of law in bills. They must be meaningfully filled with such values as: justice, equality, freedom, which are the semantic characteristics of law, express the idea of law. Thus, the RL is the rule of legal 


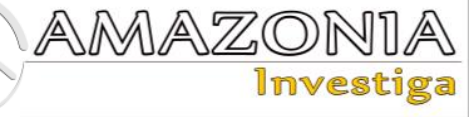

equality in justice, freedom, good, truth, etc. in social relations, regardless of the normative design. The emphasis in the interpretation of the RL of the Constitutional Court of Ukraine is on the legal content, not the form of law (Bratasyuk, 2015).

The Constitutional Court of the Republic of Lithuania stated, in particular in its decisions of 13 December 2004, 17 November 2011, etc., that the constitutional PRL is a universal principle on which the entire Lithuanian legal system and the Constitution itself are based. This principle is an extremely capacious constitutional principle that encompasses many interrelated imperatives; its content should be disclosed in the light of various other constitutional principles, such as the rule of the Constitution, the sovereignty of the nation, democracy, good governance, the limitation of powers and the maintenance of public institutions. Thus, the constitutional PRL is linked, inter alia, to constitutional principles such as the sovereignty and democracy of the nation. In addition, the above-mentioned court emphasizes the connection between the RL and the responsibility of the state, noting that the government's responsibility to society is the RL enshrined in the Constitution, which states that the government serves the people and that citizens have the right to participate in the governance of their country, directly and through democratically elected representatives to defend their rights in court, etc. (Keturakene, Lubauskas, Sinkevičius, \& Jalimas, 2020).

In turn, the Federal Constitutional Court of Germany expressed in its decision the vision of the RL as a bearer of ideas of justice that allow and require consideration of the interests of a properly functioning criminal justice system (Case No. 2BvR2025/07, 2009).

Thus, this judicial institution drew attention to the need to ensure the interests of the state as a direct participant in the introduction and establishment of the RL, thus once again consolidating the need to balance interests in the relationship "man-state".

In turn, in order to overcome the declarative PRL, it is advisable to interpret it by courts of general jurisdiction, not just constitutional, as proclaimed at the constitutional level, this principle is enshrined in codified procedural regulations.

This shows that not only the ECtHR makes a significant contribution to the RL, but the national courts of different states within their powers also provide interpretation of this principle, which reveals exactly its content, which was enshrined in the constitution of the state, thus making such an interpretation binding on the authorities. The consolidation of the PRL in the legislative, executive and judicial plane means the consolidation and prosperity of the idea, according to which, due to the constitutional culture of the state, it is necessary to develop the concept of the RL in the legal life of society, taking into account the modern achievements of constitutional science, which is able to promote the RL.

However, there is a downside to the possibility of a formal interpretation of the RL by a large number of actors. Thus, each of the subjects of interpretation makes a significant contribution to understanding the content of the RL, but at the same time creates an accumulated array of legal opinions on this issue, which may complicate the practical application of this principle, and at worst - create contradictions. Thus, in order to overcome the declarative PRL, it is also appropriate to consider the creation of a future database, which would include the collection of court decisions, in particular the ECtHR, concerning the interpretation of this principle.

The ECtHR has repeatedly stated that the principle of legal certainty is an integral part of the RL. The position of the European Court of Human Rights is reflected in Ukrainian jurisprudence in criminal proceedings (references to decisions of the Supreme Court with such legal positions in criminal and other proceedings) (example - Application №1330/11, 2020; Application № 800/284/17, 2018). An equally important component of the RL is the application of due process. As can be seen from the case law of the Supreme Court, the application of due process is an integral part of the RL and provides, inter alia, for the powers of public authorities to be defined by law, and requires officials to authorize and continue to act within the powers granted to them (Application №640/5023/19, 2021).

In view of the above, it can be concluded that the principle of the rule of law plays an important role in criminal proceedings, consists of separate components, and its interpretation is reflected in the practice of the ECtHR. In general, the observance of the constituent parts of the principle of the RL indicates that in criminal proceedings the state is aimed at recognizing man, his rights and freedoms as the highest social values. 


\section{Conclusions}

1. An important role for the interpretation of the content, highlighting the peculiarities of the application of the RL is played by the ECtHR, a set of decisions of which demonstrates an expanded vision of the latter principle.

2. The ECtHR interprets the RL, through the prism of articles of the Convention, and focuses on the quality of law, in particular within the lawful restrictions on the exercise of human rights and freedoms, access to justice and a fair trial, authorities, etc.

3. The aspects of the RL highlighted by the ECtHR could be normatively enshrined and the basis for the introduction of the delimitation of the substantive PRL into individual components, which in turn would serve to eliminate the declarative nature of this principle.

4. A fundamental role in establishing the PRL and overcoming its declarativeness is played by the national constitutional courts of states that have proclaimed the PRL in their constitutions, as these courts states.

5. Within the framework of the activity of higher judicial bodies, first of all, constitutional courts, the direct application of the RL shall be ensured and its effectiveness at the level of national legal systems shall be guaranteed.

6. The legal positions of constitutional national courts are an important tool for ensuring the doctrine of the RL and its implementation in legal reality.

7. The lack of a normatively established definition of the PRL and its components, as well as the lack of systematization of legal conclusions on the interpretation of the RL are negative factors in adhering to the RL.

\section{Bibliographic references}

Bolokan, I., Samoylenko, G., Tkalych, M., Panchenko, B., \& Dmytriv, V. (2021). Sanciones en el deporte La relación entre la regulación legal y local (Sanctions in Sport: The Relationship Between Legal and Local Regulation). Retos, 42, 662-672. https://doi.org/10.47197/retos.v42i0.88681

Bratasyuk, M. (2015). The PRL as a constitutional basis for the legal development of modern Ukraine. [File PDF]. Recovered from https://cutt.ly/NUoAXQc.

Butkevych, V. (2011). The quality of the law and the issue of the effectiveness of the application of the decisions of the European Court of Human Rights by the courts of
Ukraine. Law of Ukraine, 7, 48-63. [in Ukrainian]

Case No. 1-33/2004. Unified register of court decisions of Ukraine, 2004. Recovered from https://zakon.rada.gov.ua/laws/show/v015p7 10-04\#Text.

Case No. 2BvR2025/07. Federal Constitutional Court of Germany, 2009. Recovered from https://www.bundesverfassungsgericht.de/Sh aredDocs/Entscheidungen/DE/2009/03/rk20 090318_2bvr202507.html.

Case of Golder v. The United Kingdom, Application No. 4451/70, A/18. Decision of the European Court of Human Rights, 1975. Recovered from http://hudoc.echr.coe.int/app/conversion/pdf/ ?library=ECHR\&id=001-

57496\& filename $=001$ 57496.pdf\&TID=aauoturhlg

Case of Malone v. The United Kingdom, Application No. 8691/79. Decision of the European Court of Human Rights, 1984. Recovered from https://cutt.ly/jUyvfXT.

Case of Shchokin v. Ukraine, Application No. 23759/03. Decision of the European Court of Human Rights, 2010. Recovered from http://hudoc.echr.coe.int/app/conversion/pdf/ ?library=ECHR\&id=001100944\&filename=001-100944.pdf

Case of Amuur v. France, Application No. 19776/92. Decision of the European Court of Human Rights, 1996. Recovered from https://cutt.ly/eUyx51O.

Case of Campbell and Fell v. The United Kingdom, Application No. 7819/77. Decision of the European Court of Human Rights, 1984. Recovered from https://cutt.ly/0UyvOFx.

Case of Funke v. France, Application No. 10828/84. Decision of the European Court of Human Rights, 1993. Recovered from https://hudoc.echr.coe.int/tur\#\{\%22itemid\% 22:[\%22001-57809\%22]\}

Case of Hornsby v. Greece, Application No. 18357/91. Decision of the European Court of Human Rights, 1997. Recovered from http://hudoc.echr.coe.int/app/conversion/pdf/ ?library=ECHR\&id=001$58020 \&$ filename $=001-58020$. pdf

Case of Kruslin v. France, Application No. 11801/85. Decision of the European Court of Human Rights, 1990. Recovered from http://hudoc.echr.coe.int/app/conversion/pdf/ ?library $=$ ECHR\&id $=001-$ 57626\&filename $=001-57626$.pdf

Case of Olsson v. Sweden, Application No. 10465/83. Decision of the European Court of Human Rights, 1988. Recovered from https://cutt.ly/0Uyc91B. 


\section{AMAZONZA}

Case of Volokh v. Ukraine, Application No. 474/32. Decision of the European Court of Human Rights, 2006. Recovered from http://hudoc.echr.coe.int/webservices/conten t/pdf/001-77837?TID=ihgdqbxnfi

Case No. 1-330/11 (Unified register of court decisions of Ukraine, February 24, 2020). Recovered from: https: // reyestr.court.gov.ua/Review/87794003.

Case No. 800/284/17 (Unified register of court decisions of Ukraine, February 28, 2020). Recovered https://reyestr.court.gov.ua/Review/7252545 8.

Case No. 640/5023/19 (Unified register of court decisions of Ukraine, May 24, 2020). Recovered https://reyestr.court.gov.ua/Review/9728625 3.

Keturakene, A., Lubauskas, V., Sinkevičius, V., \& Jalimas, D. (Eds.). (2020). Official Constitutional Doctrine: Key Provisions (1993-2020). Vilnius: Constitutional Court of the Republic of Lithuania. ISBN 978-9955688-49-5 Recovered from https://www.lrkt.lt/data/public/uploads/2020/ 10/oficialioji-konstitucine-doktrina-web.pdf.

Kharytonov, E., Kharytonova, O., Kostruba, A., Tkalych, M., \& Tolmachevska, Y. (2020). Las peculiaridades de la regulación legal y no legal de las relaciones sociales en el ámbito del deporte (To the Peculiarities of Legal and Non-Legal Regulation of Social Relations in the Field of Sport). Retos, 41, 131-137. https://doi.org/10.47197/retos.v0i41.84178

Kharytonov, E., Kharytonova, O., Tkalych, M., Bolokan, I., Samilo, H., \& Tolmachevska, Y. (2021). Intellectual property law in the field of sports: specifics of manifestations and features of legal regulation. Cuestiones Políticas, 39(69), 530-546. Recovered from https://doi.org/10.46398/cuestpol.3969.33
Kolomoiets, T., Tkalych, M., Melnyk, P., Panchenko, B., \& Tolmachevska, Y. (2021). Combating Corruption in Sport: Legal Aspect. Retos, 41, 746-755. https://recyt.fecyt.es/index.php/retos/article/ view/86975

Kozyubra, M., Pogrebnyak, S., Tselev, O., \& Matveeva, Yu. (2015). General theory of law. Kyiv: Waite. Recovered from https://www.osce.org/files/f/documents/8/f/2 83756.pdf.

Kryzhova, O. (2016). The structure of the PRL: analysis through the prism of its law enforcement. Bulletin of the National University "Lviv Polytechnic". Series: Legal Sciences, 837, 149-153. Recovered from https://cutt.ly/1UxU561.

Matveeva, Yu. (2019). The principle of legal certainty as a component of the RL. (doctoral thesis). National University "Kyiv-Mohyla Academy", Kyiv. Recovered from https://cutt.ly/eUxIVFQ.

Pukhtetska, A. (2010). The principle of the rule of law: modern European doctrines as a guide for reforming national legislation. Bulletin of the National Academy of Sciences of Ukraine, 3, 33-43. Recovered from http://dspace.nbuv.gov.ua/bitstream/handle/1 23456789/27214/05-

Pukhtetska.pdf?sequence $=1$

Temchenko, V. (2007). RL in the practice of the European Court and the Constitutional Court of Ukraine. Proceedings. Legal sciences, 64, 15-20. Recovered from http://ekmair.ukma.edu.ua/bitstream/handle/ 123456789/6984/Temchenko_Verkhovenstv o_prava.pdf?sequence $=5$ \&isAllowed $=y$

Verkhovna Rada of Ukraine (1950). Convention for the Protection of Human Rights and Fundamental Freedoms. Recovered from https://zakon.rada.gov.ua/laws/show/995_00 4\#Text. 